Stewart H. Rewoldt

\title{
Need We Fear Japanese Competition?
}

\begin{abstract}
ATER Years of relative indifference, Americans have suddenly become acutely aware of foreign trade and competition. For the first time in recent history, we have a balance-of-payments problem. Expenditures abroad by the government and private citizens are exceeding purchases from the United States by other nations, causing a heavy outflow of gold from our country in settlement of international claims. Unemployment is high in some industries hard hit by foreign competition. These facts are cause for concern and have stimulated a general re-evaluation of our foreign trade policies; the government has taken steps to restore balance in our international accounts, and is contemplating further action. In addition, many suggestions for handling the present situation have been made. Some will help to correct the problems without doing long-run damage to the position of

Mr. Rewoldt is Professor of Marketing in the School of Business Administration, University of Michigan. He recently spent one year in Japan as Adviser, Institute for Research in Productivity, Waseda University, Tokyo.
\end{abstract}

the United States in international trade. Some proposals, however, based on uninformed opinion and a misunderstanding of foreign trade, will perhaps solve the present problems, but only at the expense of our future position in the world market.

Competition from Japan, more than that from any other country, has been widely recognized as a threat to U.S. industry. The results of one survey ${ }^{1}$ show that over one-third of those interviewed oppose trade with Japan because they feel that it will harm the United States economy. There was more opposition only to trade with Soviet Russia. This attitude toward trade with Japan is held despite the fact that we trade less with Japan than with a number of other countries, and also despite the fact that the United States sells more to Japan than we buy in return. It is the purpose of this article to review trade between the two countries, to consider whether such trade is a threat

\footnotetext{
1 "Buying Japanese," Business Week (September 19, 1959), p. 150.
} 
TABLE 1

Japanese Trade with the United States, 1954-58

(in millions of dollars)

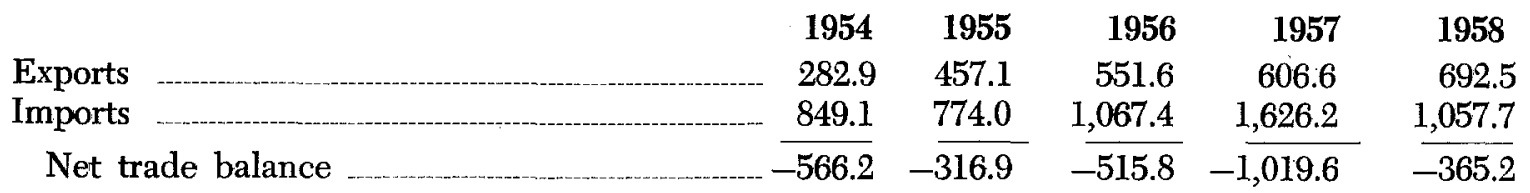

Source: Statistical Office of the United Nations Department of Economic and Social Affairs, Yearbook OF INTERNATIONAL TRADE STATISTICS: 1958 (New York, 1959), p. 328.

to the economic welfare of the United States, to evaluate the competitive strength of Japanese industry, and to reach conclusions concerning what actions, if any, should be taken regarding such trade. Although the conclusions will apply specifically to JapaneseUnited States trade, they are also suggestive of what our position should be concerning international trade in general.

\section{THE TRADE P ICT URE}

Our imports from Japan have been increasing at a rapid rate in recent years. From $\$ 282.9$ million in 1954 , imports rose to $\$ 692.5$ million by 1958 , an increase of 145 per cent in four years. During the first three quarters of 1959 , imports amounted to $\$ 726.4$ million, more than the total for the full year of 1958. For all of 1959, Japanese exports to the United States exceeded those of the previous year by 50 per cent. Our sales to Japan, on the other hand, increased only 2 per cent during 1959 . In the first quarter of 1960, the demand for Japanese products continued to increase, raising our imports from Japan 31.2 per cent. This upward trend began to falter in the second quarter of 1960 when the rate of increase fell to 12.7 per cent. During the third quarter, the growth was less than 1 per cent. ${ }^{2}$ It is, however, too early

\footnotetext{
2Mitsubishi Economic Research Institute, Monthly Cir cular, Survey of Economic Conditions in Japan (December, 1960$)$, p. 8 .
}

to tell if this recent decrease in demand for Japanese products in the United States is only temporary or if this constitutes the end of the long upward trend.

At first glance, Japan's increase in exports to the United States seems ominous, and results in cries for action to halt the flood of Japanese products. But when this situation is looked at in proper perspective (see Table 1), it is less evident that a need for drastic action exists. Japan's exports to the United States have increased rapidly-but from a very low base. If we consider only the exchange of identifiable products between the two countries (and this is the pertinent comparison if we are trying to assess relative competitive effectiveness ), Japan has, year in and year out, suffered a deficit in trade with the United States. The United States has recognized Japan's need for removing this deficit and has been, in general, sympathetic to actions taken by Japan toward this end. Not much progress in this direction was made before 1959. The problem was made extremely difficult by the heavy dependence of the Japanese economy on imports, particularly imports from the United States. These imports could not be reduced without unfavorable effects upon the Japanese economy. Thus the only available approach was to attempt to increase exports in order to earn the funds necessary for these indispensable imports. The efforts to do this have at last begun to bear fruit. 


\section{CAUSE FOR CONCERN?}

It is interesting to speculate why there is so much concern about imports into the United States market from Japan when, in fact, the Japanese have long been better customers for us than we have been' for them. Perhaps there are many reasons for this attitude, but three factors appear to be of primary importance. First, the trend in Japan's exports to the United States has been consistently upward over a long period, while no such upward trend is evident in our exports to Japan. Second, imports from Japan make a big impression on the consumer market and compete directly with American-made goods; this is not true of our exports to Japan. Third, imports from Japan tend to be concentrated in certain product lines and often represent a significant share of sales for these types of products in our market.

\section{The Trend}

Table 1 shows a consistent and substantial increase in Japan's exports to the United States since 1954. In fact, such exports have been rising ever since the end of World War II. Although our exports to Japan have been consistently larger than our purchases from that country, they have fluctuated widely and no upward trend is evident. A simple extrapolation of these trends leads to the conclusion that the U.S. will soon be buying far more from Japan than it will be selling to Japan. Should this occur, it would aggravate our balance-of-payments problem and perhaps reduce employment here. One of the conclusions than can be drawn from this article as a whole, however, is that these relative trends will probably not continue.

\section{Direct Competition}

Our imports from Japan are mainly consumer products: clothing, toys, chinaware, photographic equipment, transistor radios, stainless steel flatware, and so on. These products are usually branded, easily recognized as Japanese imports, and widely distributed throughout the United States. United States products exported to Japan, on the other hand, include wheat, raw cotton, scrap iron, fertilizers, and soybeans, plus a great variety of capital equipment items. Raw materials and capital goods imports do not make much of an impression on the public. Hence, there is little awareness of the volume of such imports.

In most instances, Japanese imports compete in our market with similar products of United States manufacture. This competition threatens United States industry as well as domestic employment. Politicians are sympathetic to the plight of these industries, and there has been much discussion in Congress and elsewhere about what should be done to help them. A similar reaction does not occur in Japan. Japan lacks raw materials of most kinds, and, as a result, imports from the United States do not compete with Japanese products.

\section{Concentration of Exports}

Although many different goods are imported into the United States from Japan, there is a significant degree of concentration in a few classes of products. In the first half of 1959, over two million Japanese radios were shipped to this country. Over 90 per cent of the chinaware purchased in the U.S. is imported, mostly from Japan. In 1958, Japanese stainless steel Hatware exports to the United States equaled one-half of our domestic output. Photographic goods imported from Japan rose from $\$ 1.2$ million to $\$ 28.2$ million between 1954 and 1958. These are dramatic figures, and they reflect a major competitive threat to several United States industries. Our sales to Japan, with a few exceptions (cotton, for example), represent just a small percentage of total United States output of these products. It thus appears to many people that some of our industries are suffering substantially from Japanese competition, while others are benefiting only modestly from their exports to Japan. 
Under these circumstances, it is easy to forget that it is Japan that traditionally suffers a deficit in its trade with the United States.

\section{JAPAN'S ECONOMY}

Although our trade relations with Japan have in the past been satisfactory, it is possible that our imports will continue to rise while our exports do not keep pace. This imbalance is unlikely to happen in the near future because Japan appears willing to remove restrictions on imports from the United States in order to prevent it. Our exports to Japan in 1960 increased 37 per cent over 1959 after the Japanese government lifted import restrictions on 270 items. The likelihood of a severe imbalance of trade in the future will depend largely on the relative competitive strength of United States and Japanese industry. A closer look at the Japanese economy and its industry will be helpful in determining the effectiveness of our competition with Japanese industry.

\section{Over-All Strength}

The present state of health of Japan's economy looks good indeed. In the period from 1950 to 1953, Japan's gross national product grew at an annual rate of over 10 per cent. This high level was due in part to the Korean conflict. From 1953 to 1957 , the annual rate of growth was about 7 to 8 per cent. The year 1958 was a bad one for Japanese exports because of the recession in the United States, but in 1959 the rate of growth climbed to an astonishing 16 per cent, thus making up all at once for the lack of growth the year before. In 1960, the Japanese economy grew at a rate of 12 per cent. In order to see the growth of the Japanese economy in perspective, it must be noted that in this same decade the United States economy was growing at an annual rate of around 3 per cent.

The rapid growth of Japan's economy is due mainly to the growth of industrial production.
Industrial production indexes for the period $1950-57(1934-36=100)$ are as follows:

$\begin{array}{rrrrr}\mathbf{1 9 5 0} & 93 & \mathbf{1 9 5 4} & 167 \\ \mathbf{1 9 5 1} & 118 & \mathbf{1 9 5 5} & 190 \\ \mathbf{1 9 5 2} & 131 & \mathbf{1 9 5 6} & 232 \\ \mathbf{1 9 5 3} & 161 & \mathbf{1 9 5 7} & 263\end{array}$

These data reflect an average annual rate of increase in industrial production of 16 per cent between 1950 and 1957. It should be remembered, however, that this rate of growth was built on a very low base. Reflected here is a "catching up" with other countries, since Japanese industry was virtually wiped out at the end of World War II. Also, this rapid rate of growth is not likely to continue as Japan's economy reaches higher levels of maturity. As late as 1955, employment in Japan was still distributed as follows: 41.2 per cent in primary, 23.8 per cent in secondary, and 35.0 per cent in tertiary or service industries. The United States, in contrast, has only 4.3 per cent of its employment in primary, 34.8 in secondary, and 60.9 per cent in tertiary industries. As Japan's employment in tertiary industries increases, its rate of growth will decrease.

\section{Increasing Efficiency}

Along with industrial output, productivity of Japanese labor has also been increasing at a rapid rate, as shown in Table 2. Notice, however, that it was not until 1953 that productivity reached the prewar level. The 36 per cent increase in the next three-year period, therefore, is not so hard to comprehend. Again, it reflects a "catching up" with the rest of the world and does not necessarily indicate that Japan is going to surge ahead of its competitors in international trade. Japan's productivity increase reflects a high rate of investment in industrial plant and equipment during the 1950's. From 1950 to 1958 , the percentage of Japan's gross national product invested in industrial plant and equipment was 17 per cent. $^{3}$

${ }^{3}$ Keizai Kakusho Zuzetzu, Economic White Paper, (Tokyo: Economic Planning Agency, 1960), p. 3. 
TABLE 2

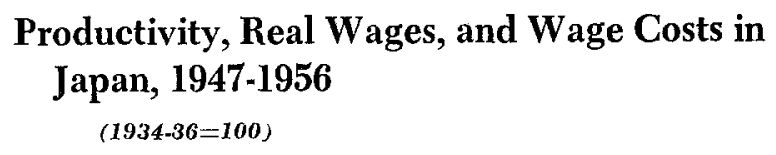

(1934-36=100)

$\begin{array}{lccc}\text { Year } & \text { Productivity } & \text { Real Wages } & \begin{array}{c}\text { Wage Costs } \\ \text { per Unit } \\ \text { of Output }\end{array} \\ 1947 & 25 & 28 & 110 \\ 1948 & 38 & 47 & 124 \\ 1949 & 49 & 59 & 122 \\ 1950 & 61 & 77 & 125 \\ 1951 & 80 & 84 & 106 \\ 1952 & 86 & 96 & 111 \\ 1953 & 103 & 103 & 100 \\ 1954 & 106 & 105 & 99 \\ 1955 & 118 & 110 & 93 \\ 1956 & 139 & 120 & 86\end{array}$

Sounce: ECONOMIC SURVEY OF ASIA AND THE FAR EAST: 1957, Economic Bulletin for Asia and the Far East (Bangkok, 1958), p. 46.

The investment in industrial plant and equipment in the United States during this same period was 9 per cent of the gross national product. In absolute terms, of course, United States investment was much larger.

During the second half of 1959 and the first half of 1960 , the author visited a large number of Japanese plants. Despite the recent heavy investment in Japanese industry, an observer cannot help but conclude that Japan is still behind the United States in most aspects of industrial efficiency.

\section{The Labor Cost Factor}

Much of the opposition in the United States to imports from Japan centers on the "cheap labor" factor; the argument is that United States industry cannot compete in trade with a nation whose labor is "exploited" in order to make low production costs possible. It is true that labor costs in Japan are low by United States standards. The average Japanese family has an income about one-seventh of the income of the average United States family. In many industries the ratio is even greater. Japan has what is often referred to as a "duoeconomy," with large firms and small firms forming separate and distinct economic structures. Wage rates in small firms are only about 40 per cent of the level in large firms. It is these low wages in small firms that are often quoted when comparisons with United States wages are made. However, these small firms are not competitive despite their low labor costs because they are inefficient and do not export in significant volume. Because it is the large-scale industry of Japan that exports to the United States, the wage rates paid in this sector are important in our discussion.

To simply compare wage rates between Japan and the United States does not tell the whole story of relative labor costs. Japanese wage costs, though lower, are relatively more fixed than in the United States. Once hired, labor in large companies in Japan tends to have permanent tenure, and employment does not fluctuate greatly with changes in volume of output. There is a strongly ingrained tradition of paternalism that provides Japanese employees with the equivalent of a guaranteed annual wage. This same attitude of paternalism means a high cost for fringe benefits such as employee housing, recreational facilities, and medical care. Employees are retired at the early age of 55 , and the company provides for all minimum needs of the retired employee and his family. Compensation in Japanese companies is based largely on seniority and family responsibility rather than on contribution. This system does not stimulate high productivity. One should also remember that the low average wage cost in Japan exists side by side with a very high cost of capital and raw materials. To a large degree, these factors offset one another.

Table 2 shows that wages have not kept pace with rising productivity in Japan, and wage costs per unit of output have declined. This is due in large measure to widespread underemployment, sometimes called "disguised unemployment," in Japan's labor market. It has been estimated that the extent of such underemployment in Japan is between 6 
and 7 million, or over 15 per cent of the labor force. Thus, as Japan's economy grows and the demand for labor rises, there is no upward pressure on wage costs. Japan's population, however, has now stabilized, and the amount of such underemployment will thus gradually be reduced as the economy grows. By 1970 or thereabouts, it probably will no longer be a major factor holding down labor costs. Also, Japanese labor unions are growing in strength, and Japanese people generally are strongly demanding a better life. Upward pressures on labor costs are bound to come.

\section{Other Competitive Weaknesses}

Japan's heavy dependence on far-flung sources of supply is probably the major competitive weakness of Japanese industry. Disproportionately high raw materials costs rule out Japan as a competitor in most cases where material costs, not labor costs, are the major part of total cost. To this must be added the fact that Japan is disadvantageously located in relation to the major markets of the free world, primarily North America and Western Europe. This rules out Japan as a strong competitor wherever transportation costs, relative to product value, are high.

Most countries are strong as exporters of those products that also have a large domestic market. This situation creates economies of scale and helps to give the exporting firm a strong position in world markets. Looked at in this light, Japan's low wage scale, which limits domestic demand, actually retards exports. In

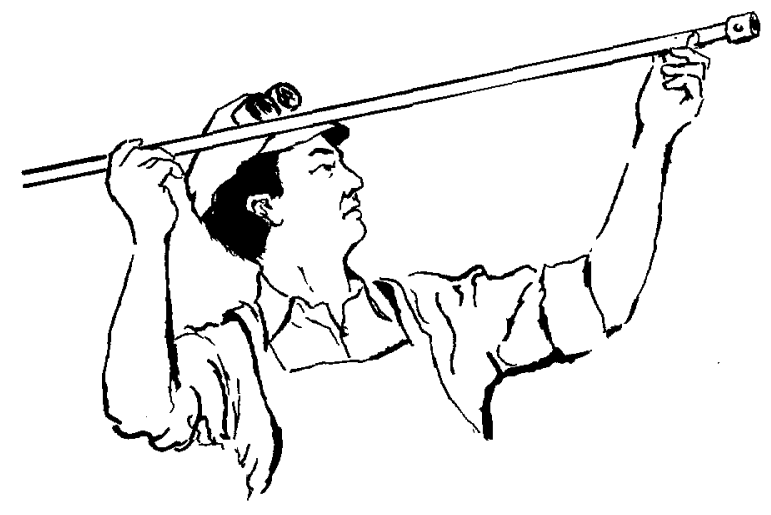

contrast to the United States, Japan has a potentially large domestic demand for relatively few products. Its export strength to date has been largely in those lines where its domestic demand is also high (for example, textiles and cameras), and it is unlikely to suddenly become a strong competitor in other fields.

Our assessment of Japan as a competitor has been based mainly on its advantages and disadvantages in production and transportation costs. It would be a serious error not to point out that Japan also suffers, and perhaps more than other areas, from a lack of sophistication in marketing. Marketing research is just beginning to be recognized in Japan, and its industry has made many mistakes because it made wrong assumptions about markets and competition. Product development in Japan is still largely a hit-or-miss affair, involving virtually no marketing research at all. Its domestic distribution system is quite inefficient, with the manufacturer often exerting little influence over the marketing of his product once it leaves his own hands. Japanese firms tend to follow the same policy abroad, selling through middlemen whose activities they do not effectively supervise or control. Perhaps this explains their heavy reliance on price to attract interest in the market. Where a low price will not sell a product, they are not aware of alternative approaches. In the future, as their cost advantage declines, their competitive price advantage can also be expected to weaken.

\section{SOME OTHER FACTORS}

On the basis of a comparison of our exports to and imports from Japan, it is obvious that the U.S. derives substantial benefits from such trade. It is, however, a mistake to reach conclusions about the benefits from trade with Japan on this basis alone; some important political factors must also be considered.

Japan occupies a position of strategic significance in our foreign policy. It is the greatest bulwark of freedom and capitalism in all of Asia; it is one of our most important military 
bases in the struggle against world communism; it is a showpiece for all the world to see of the effectiveness of free enterprise in economic development. Potentially, it is one of our strongest allies in providing aid and guidance to underdeveloped lands, particularly in Southeast Asia. Surely it is in the best interests of the United States that Japan remains strong economically.

Japan cannot remain strong economically without a healthy foreign trade. In order to keep its economy operating it must import all of its requirements for cotton, wool, rubber, phosphates, bauxite, and oil. It is heavily dependent on outside sources for wheat, sugar, soybeans, salt, and coking coal. To pay for these imports, Japan must export. If exports fail to grow, the economy cannot grow. In recent years, Japan has had to import an amount equal to about 15 per cent of its net national income. At the same time, its exports were running at a level of about 12 per cent of net national income. ${ }^{4}$

Not only is foreign trade essential to the economic well-being of Japan, but trade with the United States in particular is highly important to Japan's economy. In 1959 , some 40 per cent of Japanese imports came from the United States, which in return absorbed some 35 per cent of Japan's exports. ${ }^{5}$ This is a major shift from the prewar period when only 27 per cent of Japanese imports came from the United States and 18 per cent of its exports went to the United States. This change in the relative importance of the United States in Japan's foreign trade reflects in large part the loss of China and some other parts of Asia as sources of supply and markets. A logical alternative to trade with the United States is for Japan again to trade with these areas, now part of the Communist bloc. This might undermine Japan's position as a market for

\footnotetext{
${ }^{4} \mathrm{H}$. Michael Sapir, Japan, China, and the West (Washington, D.C.: National Planning Association, 1959), p. 12.

${ }^{5}$ Keizai Yoran, Economic Summaries, (Tokyo: Economic Planning Agency, 1959), p. 174.
}

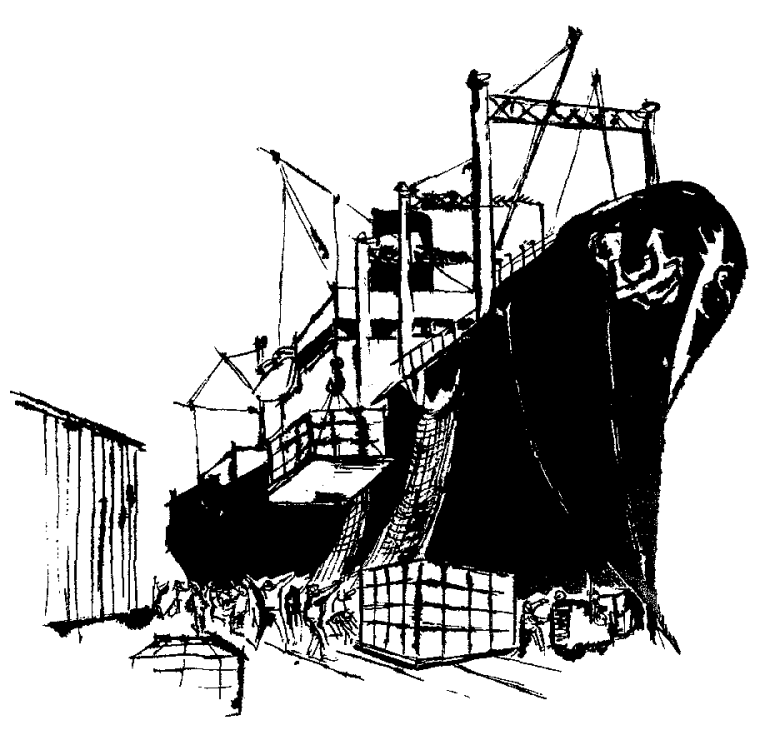

United States exports, and would certainly cause undesirable complications for our foreign policy.

With Japan so heavily dependent on imports, it follows that a healthy Japanese economy will provide a good market for United States exports. We produce many of the things that country needs. The relationship between our imports from and our exports to Japan is, however, even more direct than this. Some of the products we sell Japan go into products we, in turn, buy back. One of our major imports from Japan is cotton textiles, and Japan is by far America's best customer for raw cotton. We import steel and steel products from Japan, and the United States supplies Japan with from $33 \frac{1 / 3}{3}$ to 50 per cent of the scrap metal and 25 to 30 per cent of the coking coal needed by its iron and steel industry. Thus, action to reduce our imports from Japan would directly affect our opportunity to export. There is at present much discussion of the necessity to build United States exports to correct our balance-of-payments difficulties. Cutting our imports does not seem the best way of accomplishing this objective.

ON THE BASIS of the above evaluation, we can make the following conclusions concerning trade between Japan and the U.S.: 
1 The competitive strength of Japanese industry is increasing in relation to the competitive strength of United States industry. This narrowing of the gap is probably inevitable considering the different levels of maturity of the two economies and the greater ease with which an economy can advance in certain earlier stages.

2 It is to the advantage of the United States for Japan to be strong economically. Japan is an important customer for United States products now, and as her economy grows Japan is likely to become an even better customer. The continued economic strength of Japan is also very important from the standpoint of American foreign policy. Japan's economic strength is heavily dependent on its foreign trade and, in turn, the United States market is extremely important to the foreign trade of Japan.

3 United States industry is still more competitive than the industry of Japan. If our industry rises to the challenge of competition from Japan, it can be expected to hold its stronger position. It has no need of government help for this purpose.

4 The United States government should not set up artificial barriers restricting the sale of Japanese goods in the United States market. Rather, it should make our own businessmen aware of the opportunities for sale of United States products, both in Japan and elsewhere. A major assistance to business would be the removal of restrictions that still exist in Japan and other countries on the importation of United States products.

Our great state of California produces about sixty millions of dollars in gold every year, besides silver, quicksilver, precious stones, and many other valuable articles. Japan is also a rich and fertile country, and produces many very valuable articles. Your imperial majesty's subjects are skilled in many of the arts. I am desirous that our two countries should trade with each other, for the benefit both of Japan and the United States.

We know that the ancient laws of your imperial majesty's government do not allow of foreign trade . . . but, as the state of the world changes and new governments are formed, it seems to be wise, from time to time, to make new laws. . . [We] think that if your imperial majesty were so far to change the ancient laws as to allow a free trade between the two countries it would be extremely beneficial to both.

MILLARD FILLMORE, PRESIDENT OF THE UNITED STATES TO HIS IMPERIAL MAJESTY, THE EMPEROR OF JAPAN_-1853 